\title{
International Portfolio Diversification and Assets Allocation Bias
}

\author{
Feker Mhadhbi ${ }^{1}$ \\ ${ }^{1}$ ISG Sousse, University of Sousse, Tunisia \\ Correspondence: Feker Mhadhbi, School ISG Sousse, Rue Abdlaazizil Behi. Bp 763, 4000 Sousse, Tunisia. Tel: \\ 216-5066-9062. E-mail: feker.mhadhbi@hotmail.com
}

Received: November 12, 2012

Accepted: December 18, 2012 Online Published: January 15, 2013

doi:10.5539/ijbm.v8n3p51

URL: http://dx.doi.org/10.5539/ijbm.v8n3p51

\begin{abstract}
The purpose of this paper is to assess the evolution of home bias in assets allocation over time and to test the effect of financial markets frictions on the equities portfolio holding. Our findings show that all countries present a substantial home bias in their portfolio holding and that investors are unaware of the benefit of diversification and under-weight the foreign securities in their portfolios instead of holding the world market portfolio of risky assets, as suggested by the traditional portfolio theory. The empirical estimates based on a comparison between the version of ICAPM in the absence of frictions in financial markets and the version in the presence of friction reveal that the geography of assets trade is explained by several variables as economic and financial development and other factors related to corporate governance and the level of investor protection.
\end{abstract}

Keywords: home bias, geographical bias, portfolio diversification, capital market friction, financial development, economic development, investor protection

\section{Introduction}

In recent years, international financial markets have been remarkably overwhelmed by a wave of liberalization that has contributed to the interconnection of all markets and we are now seeing an unprecedented increase in the level of assets exchange between countries. Graph (1) gives meaning to the phenomenon of financial globalization, by measuring for 14 OECD countries the level of exchange of financial assets over the period 1997-2011(graph (2) is the same exercise for the USA).

Despite the policies adopted by countries and the considerable effort provided to open foreign markets and the gradual removal of barriers to cross-border investment, investors' portfolios do not seem sufficiently diversified and their structure is not close to that we would hope in an integrated world. Moreover, if capital markets were perfectly integrated, international investors would hold the same market portfolio of risky assets, regardless of their nationalities. However, investors still seem remarkably unaware of the benefits of international diversification and continue to tilt their holdings substantially to domestic assets. In addition, deviation from the market portfolio does not only concern the home detention, but the share internationally diversified does not seem to obey the standard theories of diversification: investors' portfolios are biased geographically and investors bias their holdings to assets which offer little domestic risk diversification. Should we therefore conclude that investors ignore completely the foundations of the theory of diversification?

The explanation for these differences between the investors of the world and the identification of factors driving the geographical bias in the allocation of portfolios is the main objective of our research work.

We begin our paper by presenting a literature review on the determinants of home and geographical bias on assets holding, or in other words, the reasons why investors from different countries would allocate their financial wealth differently. Then to identify the extent of bias in assets allocation, we evaluate the evolution of home bias over time. We finally develop an empirical model that highlights the frictions causing deviations of actual portfolios held by investors, compared with expectations of standard theories of diversification. 


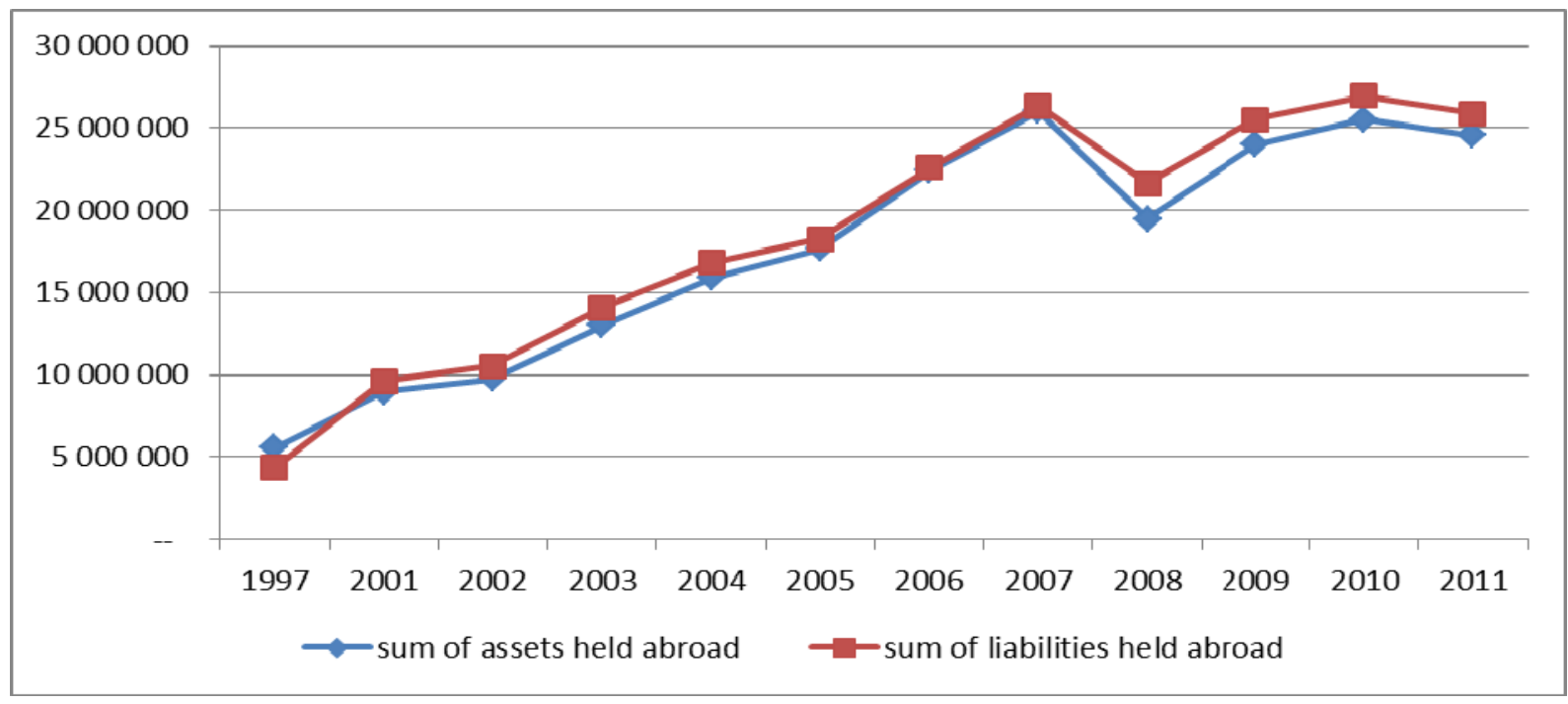

Figure 1. Sum of assets (and liabilities) of 14 OECD countries (Austria, Belgium, Canada, Finland, France, Germany, Italy, Japan, Netherlands, Spain, Sweden, United Kingdom, United States) against the rest of the world Source: Coordinated portfolio investment survey: calculation of the author.

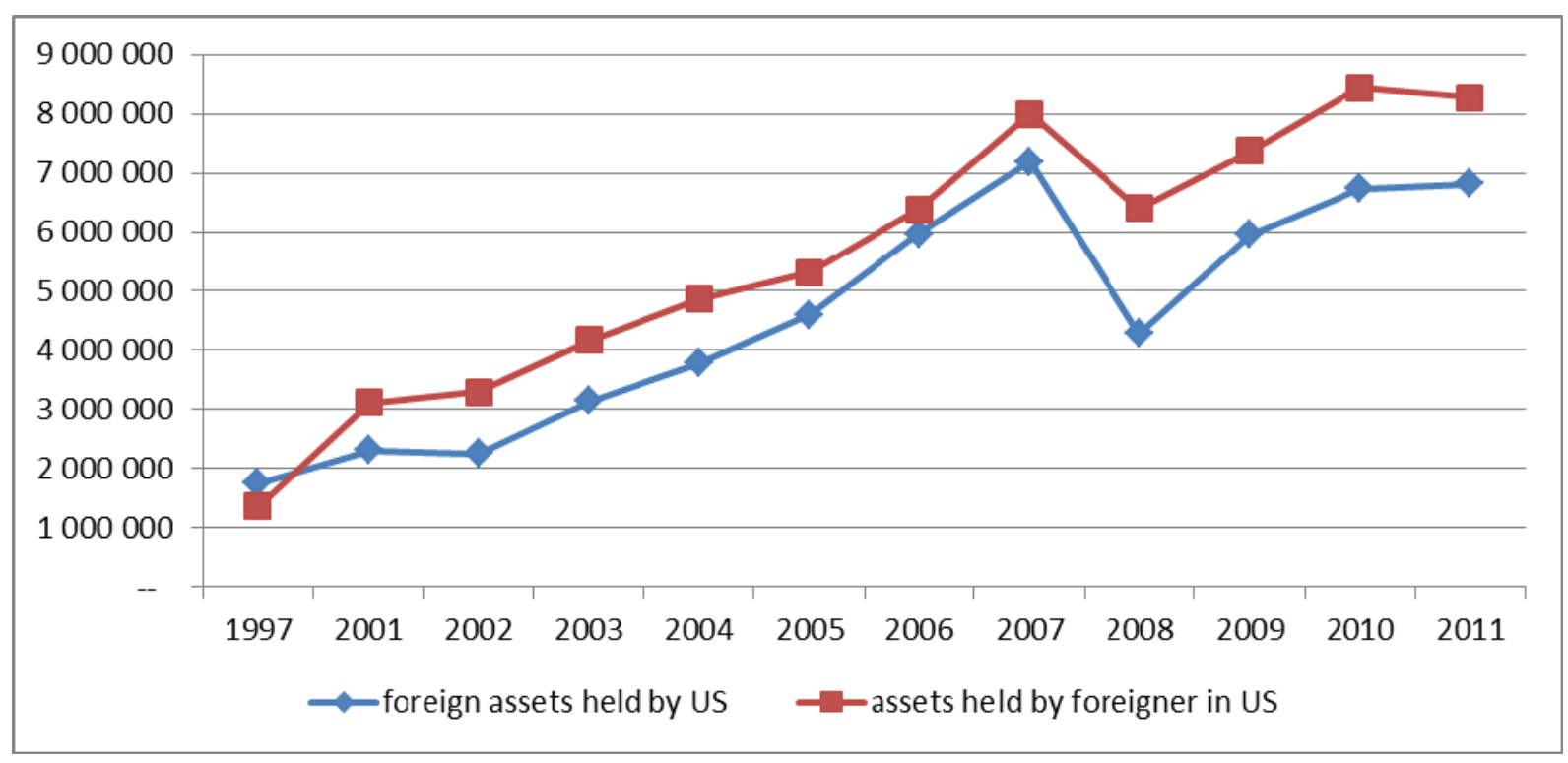

Figure 2. Assets and liabilities of the United States against the rest of the world

Source: Coordinated portfolio investment survey: calculation of the author.

\section{Literature Review}

The phenomenon of home and geographical portfolios bias has attracted a large body of theoretical and empirical research. However, the puzzle is not yet fully explored. A large part of the literature on the "home-bias in portfolio" introduces various frictions in financial markets. The essential point remains the nature of these frictions. These frictions can be explicit in nature, such as transaction costs (Martin and Rey (2004), Amadi and Burgen (2008), Coeurdacier (2009) ...), taxation of capital (Heathcote and Perri (2004), Gordon and Hines (2002) ...) or institutional restrictions on the holding of foreign assets (Bhamra (2004) ...). They can also be implicit in nature. A friction at the heart of empirical evidence on the benefits of international portfolios diversification is information asymmetry: domestic investors may have an informational advantage on domestic stocks (Merton (1987), Gehrig (1993), Coval and Moskowitz (1999, 2001), Dahlquist and Robertsson (2001), Ahearne and al. (2004), Portes and Rey (2005), Coeurdacier (2009), Barron and Ni (2008), Mondria and Wu (2010), etc. ..). Thus, the exchanges of assets between two countries are a growing function of informational 
exchanges between the two economies.

Another explanation of the portfolio bias through behavior-based is the notion of familiarity. Several studies have developed behavioral models where domestic investors consider foreign markets as riskier than they really are, simply because they are foreigners. Investors are more familiar with domestic or geographically close stocks and feel a general feeling of discomfort or fear toward foreign or remote assets (Hubermann (2001)). It thus seems that the bias favoring the familiar does not reflect the exploitation of the informational advantage, but reflects the tendency of individuals to be optimistic about the comfortable and the familiar. As investors should tilt the weight and portfolios to assets with higher expected returns, they consider more favorable the securities with which they are familiar and think that they are more likely to generate higher yields with lower specific risks, which tilts investor's portfolios to the familiar stocks (Strong and Xu (2003), Kilka and Weber (1997), Barber and Odean (2001, 2002), Karlsson and Nordén (2007), Magi (2009)).

In general, foreign securities are purchased not only for the benefit of diversification, but also for their potential benefit to outperform domestic stocks (Staman (1999)). However, when foreign securities underperform domestic securities, investors feel the pain of regret. According to the theory of regret, investors are supposed to build their portfolios taking into account simultaneously their risk aversion and regret. Solnik (2008) points out that foreign risk aversion is the sum of regret aversion and traditional measure of risk aversion. The home bias can be then expressed as a function of market variables and parameters of risk/regret aversion. Other approaches inspired by the theory of perspective and comparable to the theory of regret also had implications for international portfolio diversification, such as theories that introduce the notion of loss or disappointment aversion (Barberis and Huang (2007)).

Based on the theories of corporate governance, a variety of studies (Dahlquist et al. (2003), Stulz (2005), Pinkowitz et al. (2002), Kho et al. (2009), etc ...) argue that moral hazard in the context of the management of firms remains an important source of bias in asset allocation: the insiders of firms can expropriate small investors or minority or foreign shareholders. To remedy this standard problem of agency and align incentives for optimal management of the company, the "insiders" are provided with some of the stocks of the company. This ownership structure where sub-optimally diversified and observed in most developed and emerging countries (family firms, minority control, stock options ...).

\section{Measurement of Home Bias in Equity Portfolio Holdings}

We measure the home bias in country i as the difference between the relative real share of domestic equities in the overall portfolio of domestic investors and the relative share of domestic market capitalization of the country in the world capitalization.

$$
H B=\text { real share of domestic holding }-\left[\frac{\text { domestic capitalisation }}{\text { world capitalisation }}\right]
$$

Actual portfolios holdings are determined using data from international investment positions. More specifically, the holdings of domestic stocks are calculated as the difference between the market capitalization of the country $\left(\mathrm{MC}_{\mathrm{i}}\right)$ and the sum of all domestic stocks held by foreign investors $\left(\mathrm{FL}_{\mathrm{i}}\right)$.

$$
\text { actual share of domestic holdings }=\frac{M C_{i}-F L_{i}}{F A_{i}+M C_{i}-F L_{i}}
$$

Where:

$\mathrm{FL}_{\mathrm{i}}$ : all foreign equities of country $\mathrm{i}$ held by the rest of the world.

$\mathrm{FA}_{\mathrm{i}}$ : the sum of all stocks of the rest of the world held in country $i$.

$\mathrm{FA}_{\mathrm{i}}+\mathrm{MC}_{\mathrm{i}}-\mathrm{FL}_{\mathrm{i}}$ represent the total portfolio of domestic investors. These values are not directly available from the CPIS database. The CPIS data include only foreign equity securities held by domestic investors, not domestic securities held by domestic investors.

Table (1) provides an overview of changes at the level of home bias in equity for the period from 1997 to 2011.

Data on cross-border equity holdings are obtained from the database "Coordinated Portfolio Investment Survey (CPIS)" of the International Monetary Fund (IMF). Data on stock market capitalization are obtained from "World Federation of Stock Exchanges". 
Table 1. Change in home bias in equities between 1997 and 2007

\begin{tabular}{|c|c|c|c|c|c|c|c|}
\hline Pays & 1997 & 2001 & 2002 & 2003 & 2004 & 2005 & 2006 \\
\hline Argentine & 0.8051 & 0.8166 & 0.6906 & 0.8136 & 0.8186 & 0.8252 & 0.8039 \\
\hline Australia & 0.8662 & 0.8138 & 0.7964 & 0.8174 & 0.8284 & 0.8160 & 0.8206 \\
\hline Austria & 0.7236 & 0.3801 & 0.4679 & 0.4880 & 0.5124 & 0.5748 & 0.5908 \\
\hline Brazil & 0.9867 & 0.9737 & 0.9722 & 0.9784 & 0.9826 & 0.9809 & 0.9793 \\
\hline Belgique & 0.6464 & 0.5443 & 0.4647 & 0.4666 & 0.7896 & 0.4872 & 0.4179 \\
\hline Canada & 0.8222 & 0.6959 & 0.6752 & 0.6929 & 0.7211 & 0.7196 & 0.7018 \\
\hline Chili & 0.9908 & 0.9284 & 0.9093 & 0.8820 & 0.8751 & 0.8463 & 0.7860 \\
\hline Denmark & 0.7771 & 0.5802 & 0.6153 & 0.6306 & 0.6195 & 0.6196 & 0.4787 \\
\hline Egypt & 0.9868 & 0.9733 & 0.9816 & 0.9815 & 0.9779 & 0.9861 & 0.9879 \\
\hline Finland & 0.9373 & 0.7894 & 0.7101 & 0.6645 & 0.6134 & 0.6316 & 0.6108 \\
\hline France & 0.8059 & 0.8088 & 0.7943 & 0.7637 & 0.7455 & 0.7162 & 0.7296 \\
\hline Germany & 0.8141 & 0.6366 & 0.5666 & 0.5949 & 0.5631 & 0.5443 & 0.5755 \\
\hline Greece & 0.9834 & 0.9789 & 0.9561 & 0.9464 & 0.9397 & 0.9299 & 0.9209 \\
\hline Hongkong & 0.8834 & 0.7992 & 0.7880 & 0.7786 & 0.7674 & 0.7766 & 0.7766 \\
\hline Hungry & 0.9956 & 0.9631 & 0.9704 & 0.9719 & 0.9356 & 0.9050 & 0.8150 \\
\hline India & - & - & - & - & 0.9797 & 0.9738 & 0.9683 \\
\hline Indonesia & 0.9976 & 0.9982 & 0.9949 & 0.9978 & 0.9971 & 0.9965 & 0.9940 \\
\hline Israel & 0.9697 & 0.9493 & 0.9393 & 0.9401 & 0.9358 & 0.9103 & 0.9067 \\
\hline Italia & 0.7640 & 0.6101 & 0.5751 & 0.5612 & 0.5826 & 0.5527 & 0.5435 \\
\hline Japon & 0.7608 & 0.7776 & 0.7656 & 0.7848 & 0.7771 & 0.7575 & 0.7841 \\
\hline Korea & 0.9715 & 0.9836 & 0.9790 & 0.9739 & 0.9564 & 0.9563 & 0.9276 \\
\hline Malta & 0.9976 & 0.9873 & 0.9492 & 0.9004 & 0.8216 & 0.8306 & 0.7880 \\
\hline Malaysia & 0.9989 & 0.9831 & 0.9787 & 0.9889 & 0.9886 & 0.9858 & 0.9771 \\
\hline Mexico & 0.9956 & - & - & 0.9911 & 0.9733 & 0.9755 & 0.9711 \\
\hline Colombia & 0.9972 & 0.9768 & 0.9585 & 0.9461 & 0.9758 & 0.9787 & 0.9704 \\
\hline Norway & 0.8444 & 0.5605 & 0.4802 & 0.4875 & 0.5181 & 0.5147 & 0.5204 \\
\hline New Zealand & 0.8162 & 0.6523 & 0.6512 & 0.6427 & 0.6423 & 0.5899 & 0.5998 \\
\hline Netherlands & 0.6831 & 0.4012 & 0.4138 & 0.3223 & 0.3596 & 0.2951 & 0.3052 \\
\hline Philippine & 0.9981 & 0.9928 & 0.9918 & 0.9909 & 0.9919 & 0.9955 & 0.9966 \\
\hline Poland & 0.9956 & 0.9939 & 0.9913 & 0.9916 & 0.9861 & 0.9767 & 0.9580 \\
\hline Portugal & 0.8559 & 0.8060 & 0.7868 & 0.7980 & 0.7609 & 0.7502 & 0.7023 \\
\hline Singapore & 0.8380 & 0.7171 & 0.6755 & 0.7470 & 0.7293 & 0.7004 & 0.7483 \\
\hline South Africa & 0.8966 & 0.7119 & 0.7754 & 0.8497 & 0.8893 & 0.8756 & 0.8929 \\
\hline Spain & 0.8956 & 0.8405 & 0.8519 & 0.8568 & 0.8493 & 0.8386 & 0.8337 \\
\hline Sweden & 0.9877 & 0.5968 & 0.5611 & 0.5828 & 0.5884 & 0.5838 & - \\
\hline
\end{tabular}




\begin{tabular}{|c|c|c|c|c|c|c|c|}
\hline Switzerland & 0.5567 & 0.5487 & 0.5875 & 0.5806 & 0.5767 & 0.5738 & 0.5913 \\
\hline Thailand & 0.9964 & 0.9957 & 0.9957 & 0.9917 & 0.9895 & 0.9865 & 0.9817 \\
\hline Turkey & 0.9979 & 0.9970 & 0.9970 & 0.9969 & 0.9960 & 0.9953 & 0.9955 \\
\hline UK & 0.6920 & 0.6408 & 0.6199 & 0.6239 & 0.5977 & 0.5565 & 0.5508 \\
\hline USA & 0.3169 & 0.3685 & 0.3951 & 0.4064 & 0.4136 & 0.4068 & 0.4149 \\
\hline Pays & 2007 & 2008 & 2009 & 2010 & 2011 & \multicolumn{2}{|c|}{ Variation 1997/2011 } \\
\hline Argentine & 0.7762 & 0.9488 & 0.8903 & 0.9206 & 0.8957 & \multicolumn{2}{|c|}{0.0906} \\
\hline Australia & 0.7733 & 0.7514 & 0.7539 & 0.7493 & 0.9747 & \multicolumn{2}{|c|}{0.1085} \\
\hline Austria & 0.6147 & 0.4157 & 0.4829 & 0.4591 & 0.2683 & \multicolumn{2}{|c|}{-0.4553} \\
\hline Brazil & 0.9714 & 0.8083 & 0.7801 & 0.7817 & 0.7906 & \multicolumn{2}{|c|}{-0.1961} \\
\hline Belgique & 0.4330 & 0.4525 & 0.4201 & 0.4356 & 0.4251 & \multicolumn{2}{|c|}{-0.2213} \\
\hline Canada & 0.7174 & 0.7071 & 0.7095 & 0.7036 & 0.6993 & \multicolumn{2}{|c|}{-0.1229} \\
\hline Chili & 0.7521 & 0.9180 & 0.9139 & 0.9208 & 0.9943 & \multicolumn{2}{|c|}{0.0035} \\
\hline Denmark & 0.5021 & 0.8985 & 0.9020 & 0.8913 & 0.8901 & \multicolumn{2}{|l|}{0.113} \\
\hline Egypt & 0.9888 & 0.9227 & 0.8971 & 0.8707 & 0.8850 & \multicolumn{2}{|c|}{-0.1018} \\
\hline Finland & 0.6090 & 0.5536 & 0.5611 & 0.5489 & 0.5402 & \multicolumn{2}{|c|}{-0.3917} \\
\hline France & 0.7215 & 0.6652 & 0.6728 & 0.6543 & 0.6012 & \multicolumn{2}{|c|}{0.2047} \\
\hline Germany & 0.4954 & 0.4618 & 0.4389 & 0.4606 & 0.4502 & \multicolumn{2}{|c|}{-0.3639} \\
\hline Greece & 0.8994 & 0.7681 & 0.7874 & 0.7884 & 0.7350 & \multicolumn{2}{|c|}{-0.2484} \\
\hline Hongkong & 0.7741 & 0.8293 & 0.8368 & 0.9506 & 0.8309 & \multicolumn{2}{|c|}{-0.0525} \\
\hline Hungry & 0.7707 & 0.6462 & 0.6316 & 0.5958 & 0.6170 & \multicolumn{2}{|c|}{-0.3786} \\
\hline India & 0.9694 & 0.8424 & 0.8440 & 0.7493 & 0.8683 & \multicolumn{2}{|l|}{--} \\
\hline Indonesia & 0.9935 & 0.8114 & 0.8194 & 0.8428 & 0.8516 & \multicolumn{2}{|l|}{-0.146} \\
\hline Israel & 0.9079 & 0.7497 & 0.7398 & 0.7636 & 0.7118 & \multicolumn{2}{|c|}{-0.2579} \\
\hline Italia & 0.5327 & 0.5324 & 0.5118 & 0.5001 & 0.5065 & \multicolumn{2}{|c|}{0.2575} \\
\hline Japon & 0.7846 & 0.7174 & 0.7313 & 0.7296 & 0.7240 & \multicolumn{2}{|c|}{-0.0368} \\
\hline Korea & 0.8723 & 0.7754 & 0.7771 & 0.7688 & 0.7717 & \multicolumn{2}{|c|}{-0.1998} \\
\hline Malta & - & 0.7368 & 0.7107 & 0.6301 & 0.4668 & \multicolumn{2}{|c|}{-0.5308} \\
\hline Malaysia & 0.9611 & 0.8677 & 0.8677 & 0.8629 & 0.8579 & \multicolumn{2}{|c|}{-0.141} \\
\hline Mexico & 0.9803 & 0.7788 & 0.7787 & 0.7938 & 0.8163 & \multicolumn{2}{|c|}{-0.1793} \\
\hline Colombia & 0.9706 & 0.9756 & 0.9765 & 0.9690 & 0.9617 & \multicolumn{2}{|c|}{-0.0355} \\
\hline Norway & 0.5077 & 0.5247 & 0.5128 & 0.5094 & 0.5064 & \multicolumn{2}{|c|}{0.3380} \\
\hline New Zealand & 0.5658 & 0.4767 & 0.4893 & 0.4755 & 0.4701 & -0.1297 & \\
\hline Netherlands & 0.3415 & 0.3399 & 0.3354 & 0.3210 & 0.3356 & -0.3475 & \\
\hline Philippine & 0.9961 & 0.9984 & 0.8774 & 0.8965 & 0.8982 & $-0.099 s$ & \\
\hline Poland & 0.9347 & 0.8527 & 0.8637 & 0.8409 & 0.8366 & -0.159 & \\
\hline
\end{tabular}




\begin{tabular}{lcccccc}
\hline Portugal & 0.6435 & 0.6658 & 0.6402 & 0.6398 & 0.6025 & -0.2534 \\
Singapore & 0.7364 & 0.5840 & 0.6338 & 0.6395 & 0.5777 & -0.2603 \\
South Africa & 0.9003 & 0.8806 & 0.8739 & 0.8512 & 0.8558 & -0.0408 \\
Spain & 0.8523 & 0.7893 & 0.8019 & 0.8151 & 0.8203 & -0.0753 \\
Sweden & 0.5167 & 0.5248 & 0.5158 & 0.5024 & 0.5136 & -0.4741 \\
Switzerland & 0.5475 & 0.5343 & 0.5156 & 0.5539 & 0.5263 & -0.0304 \\
Thailand & 0.9757 & 0.8048 & 0.7954 & 0.8228 & 0.8226 & -0.1738 \\
Turkey & 0.9949 & 0.8487 & 0.8439 & 0.8296 & 0.8424 & -0.1555 \\
UK & 0.5256 & 0.4709 & 0.5036 & 0.5514 & 0.5368 & -0.1552 \\
USA & 0.4371 & 0.4946 & 0.5274 & 0.5259 & 0.5032 & 0.1863 \\
\hline
\end{tabular}

The results reveal that the majority of countries exhibit a decline in domestic equity bias during this period; however, this reduction is marginal for many countries. Most countries also exhibit a steady decline in home bias after 2001 (e g. France, Finland, Netherlands, Portugal, etc ...). However, the lowest values of home bias in the sample were recorded for Netherlands, which reached the lowest value of the bias in $2005(0.29)$ and have also experienced the largest decline over the period from 1997 to 2007 (about 40\%). However, the countries of Eastern Europe, such as Poland and Hungary in addition to Greece, exhibit the highest scores of home bias in the European Union over the period of the study (about 90\%). Moreover, the average level of home bias for the countries of the European Union shows a decline of $15 \%$ over the period 1997 to 2001 . This decline is especially marked in Sweden and Austria, whose bias scores recorded decreases of $39 \%$ and $34 \%$. It is interesting to subsequently highlight the role of the introduction of the Euro in the reduction of home bias for the member countries of the European Union and, consequently, the impact of regional integration on portfolios holdings. This effect was confirmed after the accession of Poland, Hungary and Malta to the European Union, which the respective scores of home bias began to exhibit an effective deterioration from the date of their accession in 2004.

Indeed, a comparative view between developed and emerging countries shows that the latter exhibit relatively high levels of home bias relative to developed markets, highlighting the observation that a more developed financial system reflects more activity on the international financial scene. However, visual inspection of statistical reports an unexpected result; it's the gradual increase in home bias for Japan and the United States. This increase, although gradual and marginal, highlights the increased preference of investors in those countries for domestic securities and, consequently, the progressive ignorance of foundations of the standard theory of diversification. This observation also leads us to assume that investors of larger industrialized countries prefer to polarize their holdings to their developed domestic markets, due to the existence of more profitable opportunities relatively to foreign markets less developed.

\section{Data and Methodologies}

\subsection{Description of the Model}

In order to derive an empirical model, we consider two classes of asset pricing models: the ICAPM without frictions on the capital markets, and the ICAPM in the presence of barriers to international investment (Note 1). The traditional version of the CAPM has simple and clear implications for the assets diversification: investors hold the world market portfolio of risky assets regardless of their country of residence i. In this case, the share of portfolios of country i invested in country j, $W_{i j, t}^{\text {opt }}$, can be expressed as follows:

$$
W_{i j, t}^{o p t}=\frac{M C A P_{j, t}}{M C A P_{\text {World }, t}}
$$

Where:

$\mathrm{MCAP}_{\mathrm{j}, \mathrm{t}}$ is the market capitalization of country $\mathrm{j}$ at period $\mathrm{t}$. 
$\mathrm{MCAP}_{\text {world,t }}$ is the world market capitalization at period t.

This part of the market portfolio serves as a benchmark for the detention of assets portfolio, to which share of portfolio observed in real data is compared.

Thus, the idea is to calculate the held share of foreign assets predicted theoretically, $W_{i j, t}^{o p t}$, then compare it to the actual share, $W_{i j, t}^{\text {Reel }}$, observed in the data. The difference between these two values is then held into account to assess the extent of the various frictions in explaining the geographical bias in international assets allocation.

Starting mainly from the literature, the explanatory variables are categorized into the following groups: (i) economic development, (ii) capital controls, (iii) development of financial markets, (iv) familiarity, (v) protection of investors and (vi) other control variables. The basic model is as follows:

$W_{i j, t}^{\text {Reel }}=\alpha_{0}+\beta_{1} W_{i j, t}^{\text {opt }}+\beta_{2}$ GDPC $_{i}+\beta_{3} G_{\text {GPC }}+\beta_{4}$ Detresse $_{j}+\beta_{5} G G D P_{j}+\beta_{6}$ Devfin $_{i}+\beta_{7}$ Devfin $_{j}$

$+\beta_{8}$ Turnover $_{i j}+\beta_{9}$ Intercon $_{i}+\beta_{10}$ Intercon $_{j}+\beta_{11}$ Capcon $_{i}+\beta_{12}$ Capcon $_{j}+\beta_{13}$ Liability $_{j}+\beta_{14}$ sareholder $_{j}$

$+\beta_{15}$ Disclosure $_{i}+\beta_{16}$ Re turn $_{j}+\beta_{17}$ Correl $_{i j}+\varepsilon_{i j}$

\subsection{Data Description}

To better understand the causes of the deviation between actual portfolios held by investors and optimal portfolios and identify explicit and implicit factors causing differences between investors in the composition of their portfolios, we consider a set of variables that can potentially influence the structure of holdings of investors around the globe (theaverage statistics of the variables over the period 2002-2005 are presented in table (2)). These variables are categorized as follows:

Table 2. Average statistics of the variables over the period 2002-2005

\begin{tabular}{lccccccc}
\hline & GDPC & $\begin{array}{c}\text { Detress } \\
\mathbf{( \% )}\end{array}$ & $\begin{array}{c}\text { GGDP } \\
\mathbf{( \% )}\end{array}$ & $\begin{array}{c}\text { Devfin } \\
\mathbf{( \% )}\end{array}$ & $\begin{array}{c}\text { Turnover } \\
\mathbf{( \% )}\end{array}$ & Capcon & Intercon \\
\hline South Africa & 3.97 & 35.37 & 3.3 & 345.07 & 31.17 & 96.93 & 4.13 \\
Germany & 30.31 & 12.4 & 0.35 & 179.51 & 133.49 & 55.64 & 7.70 \\
Argentine & 3.70 & 32.67 & 3.98 & 73.79 & 9.55 & 28.54 & 4.32 \\
Australia & 29.42 & 8.46 & 3.03 & 214.50 & 71.11 & 63.85 & 5.04 \\
Austria & 32.60 & 6.65 & 1.21 & 149.87 & 24.97 & 47.58 & 6.90 \\
Brazil & 3.55 & 18.86 & 1.16 & 127.28 & 32.96 & 37.71 & 5.80 \\
Belgium & 30.98 & 9.98 & 1.15 & 209.75 & 37.12 & 62.97 & 7.81 \\
Canada & 28.78 & 9.7 & 2.55 & 303.76 & 59.63 & 86.2 & 7.75 \\
Chili & 5.53 & 11.49 & 4.12 & 192.77 & 9.38 & 53.48 & 7.24 \\
China & 1.40 & 6.22 & 9.23 & 172.51 & 89.80 & 47.34 & 3.47 \\
Colombia & 2.16 & 20.05 & 3.71 & 58.64 & 9.70 & 21.14 & 3.59 \\
Denmark & 41.29 & 7.55 & 1.6 & 221.17 & 58.01 & 67.90 & 8.09 \\
Egypt & 1.17 & 14.25 & 3.8 & 160.25 & 33.24 & 44.86 & 5.80 \\
Spain & 21.96 & 13.66 & 2.71 & 219.61 & 139.15 & 64.48 & 7.04 \\
USA & 38.83 & 8.21 & 2.96 & 343.02 & 124.10 & 98.258 & 7.31 \\
Finland & 32.25 & 9.62 & 2.23 & 172.21 & 115.97 & 54.08 & 6.98 \\
France & 30.83 & 11.6 & 0.93 & 183.87 & 105.03 & 56.81 & 7.62 \\
UK & 32.24 & 7.20 & 1.98 & 285.20 & 99.59 & 81.66 & 8.63 \\
Greece & 16.85 & 13.26 & 4.15 & 163.13 & 38.12 & 49.34 & 6.78 \\
Hongkong & 24.27 & 7.275 & 4.55 & 610.17 & 44.51 & 161.56 & 8.74 \\
Hungry & 8.98 & 11.42 & 3.45 & 82.67 & 52.42 & 26.63 & 7.58 \\
India & 0.60 & 13.75 & 7.33 & 154.45 & 57.71 & 44.03 & 3.65 \\
Indonesia & 1.12 & 19.18 & 4.56 & 73.74 & 39.72 & 24.65 & 3.93 \\
\hline & & & & & & &
\end{tabular}




\begin{tabular}{lccccccc}
\hline Ireland & 41.09 & 7.62 & 4.31 & 184.59 & 50.40 & 59.40 & 8.63 \\
Israel & 16.83 & 12.21 & 2.23 & 156.52 & 33.85 & 46.95 & 8.21 \\
Italia & 26.80 & 10.73 & 0.28 & 145.17 & 124.80 & 45.74 & 6.96 \\
Japan & 33.78 & 4.61 & 2.03 & 414.75 & 50.78 & 113.79 & 7.17 \\
Korea & 13.68 & 6.63 & 4.23 & 162.02 & 181.68 & 46.64 & 3.91 \\
Malaysia & 4.535 & 5.67 & 4.93 & 316.69 & 33.25 & 82.95 & 3.84 \\
Mexico & 6.74 & 0 & 1.78 & 59.18 & 23.32 & 16.92 & 4.62 \\
Norway & 52.52 & 6.44 & 1.97 & 101.48 & 83.38 & 40.60 & 6.39 \\
New Island & 21.60 & 7.02 & 3 & 159.58 & 34.19 & 47.80 & 8.19 \\
Netherland & 33.93 & 7.33 & 0.35 & 267.63 & 119.91 & 77.31 & 8.41 \\
Philippine & 1.05 & 14.91 & 4.58 & 89.26 & 14.62 & 27.45 & 3.14 \\
Portugal & 15.36 & 9.4 & -0.23 & 183.00 & 3989.21 & 51.88 & 6.33 \\
Poland & 6.35 & 21.15 & 3.01 & 55.08 & 26.12 & 21.40 & 4.14 \\
Singapour & 23.84 & 4.66 & 3.36 & 232.39 & 31.44 & 66.06 & 7.43 \\
Sweden & 34.95 & 6.28 & 2.12 & 208.81 & 109.64 & 63.04 & 6.50 \\
Switzerland & 44.94 & 4.20 & 0.55 & 396.91 & 91.82 & 111.65 & 7.48 \\
Thailand & 2.390 & 4.67 & 5.52 & 184.27 & 88.75 & 49.21 & 3.74 \\
Turkey & 3.834 & 32.38 & 6.9 & 86.92 & 155.35 & 32.51 & 4.13 \\
\hline
\end{tabular}

\section{*Economic Development}

We assume that the share of ownership of foreign assets in a particular country is closely linked to the economic development of this country. We construct several measures for economic development. The first indicator is the GDP per capita in U.S. dollars for the country of origin $\left(\mathrm{GDPC}_{\mathrm{i}}\right)$ as well as for the country of destination $\left(\mathrm{GDPC}_{\mathrm{j}}\right)$. Indeed, rich and large countries are considered attractive since investors are more informed on their subjects and therefore give their more confidence. We expect that the GDP of the country of destination is positively correlated with international portfolios holdings. However, we believe that the GDP of the country of origin is a variable more ambivalent. On the one hand, world leaders are often also the countries with a high level of technological and financial development,making it easier for investors to obtain information and therefore make it less expensive real investment abroad. On the other hand, large economies tend to be more introverted. One argument is that investors in the major economies have better investment opportunities in their own countries, making international diversification less necessary.

We also consider the growth rate of real GDP adjusted for inflation for the country of destination $\left(\mathrm{GGDP}_{\mathrm{j}}\right)$. This measure indicates whether there are profitable opportunities for diversification in emerging markets. A priori, the effect of GDP growth on the international investment is ambiguous. All things being equal, we expect that countries exhibiting rapid growth are more attractive to international investment. However, strong growth may reflect greater uncertainty and therefore higher costs of information and adverse selection. Moreover, most countries exhibiting rapid growth are also emerging countries, about which information is scarce and where the uncertainties are often important. Data on these variables are obtained from the World Development Indicators Database and the CIA World Factbook.

Statistics on average data for the period 2002 to 2005 are summarized in the appendices. These statistics show a disparity in the cross-sectional measures of economic development across countries, implying that different measures capture different aspects of economic development in each country. While the top countries in terms of GDPC are all developed countries (Switzerland (\$ 44.94), Denmark (\$ 41.29), the U.S. (\$ 38.83), etc...), the highest values of the GDP growth are recorded in emerging countries (China (10.2\%), Argentina (9.2\%), India (8.4\%), and Turkey (7.4\%)). Indeed, we recall that the variable of GDP growth is also introduced to control for the presence of profitable diversification opportunities in emerging markets. These countries are going through a phase of considerable economic growth, which is an opportunity for investors in developed countries to move towards emerging markets. 


\section{*Misery Index of the Host Country}

The misery index of a country (Detress ${ }_{\mathrm{j}}$ ) is the sum of inflation and unemployment. Launched by Robert Barro in the 70s, this index measures the degree of macroeconomic distress of a country which adds to the uncertainty about future policy and therefore to the cost of information (It could also be interpreted as variable "feeling"). The data indicate high values of this index for emerging countries (Argentina (32.67\%), South Africa (37.37\%), and Turkey (32.38\%)) and lower scores for developed countries (Switzerland (4.20\%), Britain (7.20\%), and the U.S. $(8.21 \%)$ ). We expect that a possible increase in the misery index of a country generates more implicit costs to invest in this country and consequently, the detention of the country's assets will be low. Data on inflation and unemployment are taken from CIA World Factbook.

\section{*Financial Market Development}

Indeed, the common measures for financial development are the ratio of private credit provided by the banking sector relative to GDP or M2 relative to GDP ratio. These measures focus on the banking sector. Nevertheless, these indicators may not be appropriate to measure financial market development, since a well-developed banking sector does not always imply that the equity markets are well developed. In fact, banks and stock markets may be substitutes. Therefore, we construct a new measure that is equal to the sum of domestic credit provided by the banking sector and market capitalization relative to GDP, for the country of origin ( Devfin $_{\mathrm{i}}$ ) as well as for the country of destination $\left(\right.$ Devfin $_{\mathrm{j}}$ ). Data on market capitalization are obtained from the World Federation of Stock Exchanges, and annual data on domestic credit provided by the banking sector are extracted from World Development Indicators Databases and IFS. Statistics show that high values of this measure are recorded for developed countries (Hong Kong (610.17\%), Japan (414.75\%), Switzerland (396.9\%)) against relatively low values for emerging countries (Poland (55.08\%), Mexico (59.18\%).). Indeed, we think that the impact of financial market development in the country of destination on the international portfolio holdings is clear, because international investors will be more inclined to hold securities in developed countries. These markets offer better diversification opportunities. However, the effect of financial development of the country of origin is somewhat ambiguous. On the one hand, a developed financial system reflects more activity on the international financial scene. On the other hand, developed financial markets tend to be more introverted. This can be explained by the fact that the presence of profitable diversification opportunities in the home country encourages investors to allocate more shares of their wealth domestically and ignore foreign markets.

The second variable we considered is annual turnover measured as the volume of trade in securities in the destination country relative to the country's market capitalization (Turnover ${ }_{j}$ ). This variable is an indicator of the degree of market liquidity. We expect that the ratio of turnover to be positively correlated with the level of foreign portfolio holdings. Data on the volume traded securities are extracted from the World Federation of Stock Exchanges.

\section{*Capital control (Note 2)}

Although capital controls have been greatly reduced in many countries, some countries still impose some restrictions on foreign portfolio investment and international capital flows. It is therefore likely that capital controls can still affect cross-border investment. We considered in our study two measures of restrictions on the movement of capital. The first is an index of capital controls among 13 categories of MFIs, which represents the restrictions on the freedom of households to engage in capital markets with strangers. We consider the index for the country of origin $\left(\mathrm{capcon}_{\mathrm{i}}\right)$ and the country of destination ( capcon $_{\mathrm{j}}$ ).

This measure is provided from the IMF's Annual Report on Exchange Arrangements and Exchange Restrictions (AREAER). The second measure is taken from the Economic Freedom Network. Economic Freedom Network builds an index that measures the restrictions imposed by the country on the movement of capital in international markets, assigning low scores to countries imposing more restrictions on foreign capital transactions. When domestic investments by foreigners and foreign investment by local residents are not restricted, a score of 10 is assigned to such countries. However, when these investments are restricted only in some industries (eg, banks, defense, telecommunications), a score of 8 is assigned. When these investments are permitted but regulatory restrictions slow capital mobility, countries are valued at 5 . When domestic investments by foreigners or foreign investment by local residents require government approval, such countries receive a score of 2 . Finally, a score of zero is assigned when domestic investments by foreigners and foreign investment by local require government approval. Statistics show that this indicator ranges from 0 for Indonesia and Brazil to 13 for 10 countries, including two Asian countries (Hong Kong and Singapore). We consider the index for the country of origin $\left(\right.$ intercon $_{\mathrm{i}}$ ) as well as for the country of destination $\left(\right.$ intercon $_{\mathrm{j}}$ ).

Indeed, the imposition of controls on the movement of capital in a country discourages foreign investors to hold 
securities in the companies in this country. Therefore, the degree of polarization for a foreign country will be higher when it imposes higher measures on capital controls. We therefore expect a strong influence of capital controls, (CAPCON) and (interconnection), on the home bias in equity holdings. For example, when a country has a low score index (intercon ${ }_{\mathrm{j}}$ ), domestic investors find it more difficult to invest abroad, as it requires government approval. As a result, they are forced to have a disproportionate amount of their investment in the domestic market, something that results in a home bias even higher.

\section{*Index of Investor Protection}

Doing Business assesses the level of minority shareholder protections against misuse of corporate assets by directors for business purposes. Indicators distinguish three aspects of investor protection: transparency of transactions between interested parties (index of disclosure (Disclosure $\mathrm{j}_{\mathrm{j}}$ )), legal liability in case of misuse of corporate assets (scope of leader liability index (Liability $\left.\mathrm{j}_{\mathrm{j}}\right)$ and the possibility for shareholders to sue officers and directors for misconduct (index of ease lawsuits by shareholders (Shareholder ${ }_{\mathrm{j}}$ )).

The statistics come from a survey of lawyers in corporate law and are based on stock market regulations, company law and the rules of evidence in courts. In order that these data are comparable across countries, several assumptions about the business and transactions have been retained. The values of these indices range from 0 to 10 , and higher scores imply a better investor protection. Thus, we expect that these variables are positively correlated with the detention of foreign portfolios. The average of these indices varies from 3.3 in the Philippine to 9.3 in Singapore. The data for these indicators are extracted from the Doing Business website.

\section{*Control Variables}

To control for the existence of reasonable diversification, we introduced two additional variables. The first is the correlation between monthly stock markets indices of countries of origin and destination $\left(\mathrm{Correl}_{\mathrm{ij}}\right)$. We recall that this variable should obviously be negatively correlated with foreign ownership portfolios. In fact, investors must hold foreign assets whose returns are weakly correlated with returns on domestic assets to benefit from the opportunities of international diversification. The second control variable is the return on stock market index of the destination country $\left(\right.$ Return $\left._{\mathrm{j}}\right)$. We expect that this variable is positively correlated with foreign ownership, as investors tend to invest in economies exhibiting abnormal returns and that outperform their portfolios.Descriptive statistics of the data are presented in table (3).

Table 3. Effect of explicit and implicit frictions: descriptive statistics of variables

\begin{tabular}{llllllllllll}
\hline & \multicolumn{1}{c}{ Observations } & \multicolumn{2}{c}{ Average } & \multicolumn{2}{c}{ Variance } & \multicolumn{2}{c}{ Min } & \multicolumn{3}{c}{ Max } \\
\hline & 2002 & 2005 & 2002 & 2005 & 2002 & 2005 & 2002 & 2005 & 2002 & 2005 \\
\hline$W_{i j, t}^{\text {Reel }}$ & 862 & 1184 & 0.600 & 0.550 & 2.532 & 2.170 & -0.10 & 0 & 47.430 & 39.992 \\
& & & & & & & & & & \\
$W_{i j, t}^{\text {opt }}$ & 862 & 1184 & 2.781 & 2.670 & 8.586 & 7.369 & 0.042 & 0.079 & 48.469 & 41.491 \\
GDPi & & & & & & & & & & \\
GDPj & 862 & 1184 & 2.648 & 2.882 & 0.982 & 1.061 & -0.07 & -0.301 & 3.735 & 4.157 \\
GGDPj & 862 & 1184 & 2.305 & 2.653 & 1.241 & 1.246 & -0.72 & -0.301 & 3.735 & 4.157 \\
detressj & 862 & 1184 & 2.260 & 3.774 & 2.824 & 2.280 & -10.9 & 0.1 & 8 & 10.2 \\
Devfini & 862 & 1184 & 13.603 & 11.204 & 13.221 & 5.779 & 2.4 & 3.5 & 58.25 & 30.6 \\
Devfinj & 862 & 1184 & 147.14 & 189.349 & 99.178 & 99.001 & 42.07 & 63.755 & 429.291 & 449.033 \\
Turnoverj & 862 & 1184 & 4.968 & 75.653 & 24.996 & 45.968 & 0.059 & 11.410 & 155.816 & 168.610 \\
Correlij & 862 & 1184 & 0.550 & 0.584 & 0.270 & 0.262 & -0.26 & -0.531 & 0.974 & 0.957 \\
returnj & 862 & 1184 & -7.315 & 18.380 & 11.050 & 21.345 & -45.0 & -0.452 & 13.329 & 96.274 \\
Capconi & 862 & 1184 & 6.427 & 4.874 & 2.575 & 2.748 & 0 & 0 & 9.23 & 9.17 \\
Capconj & 862 & 1184 & 5.683 & 4.231 & 3.007 & 2.775 & 0 & 0 & 9.23 & 9.17 \\
Interconi & 862 & 1184 & 6.935 & 6.150 & 1.470 & 1.605 & 2.92 & 2.94 & 8.65 & 8.78 \\
Interconj & 862 & 1184 & 6.496 & 5.820 & 1.796 & 1.617 & 2.92 & 2.94 & 8.65 & 8.78 \\
\hline
\end{tabular}




\begin{tabular}{lllllllllll}
\hline Liabilityj & 862 & 1184 & 5.164 & 5.128 & 2.336 & 2.372 & 1 & 1 & 9 & 9 \\
Shareholderj & 862 & 1184 & 6.454 & 6.466 & 1.782 & 1.810 & 3 & 3 & 10 & 10 \\
Disclosurej & 862 & 1184 & 6.830 & 6.900 & 2.609 & 2.615 & 0 & 0 & 10 & 10 \\
Opacj & 862 & 1184 & 32.576 & 32.57 & 10.879 & 10.879 & 13 & 13 & 57 & 57 \\
Corruptj & 862 & 1184 & 6.445 & 6.380 & 2.342 & 2.416 & 1.9 & 2.2 & 9.7 & 9.6 \\
CCj & 862 & 1184 & 1.151 & 1.010 & 1.054 & 1.025 & -1.12 & -0.88 & 2.46 & 2.4 \\
VACCj & 862 & 1184 & 0.885 & 0.902 & 0.727 & 0.798 & -1.58 & -1.52 & 1.57 & 1.78 \\
RQj & 862 & 1184 & 1.034 & 0.968 & 0.766 & 0.711 & -1.06 & -0.63 & 1.89 & 1.8 \\
RLj & 862 & 1184 & 1.006 & 0.941 & 0.874 & 0.881 & -1.01 & -0.86 & 1.94 & 1.97 \\
PSj & 862 & 1184 & 0.568 & 0.364 & 0.888 & 0.792 & -2.06 & -1.81 & 1.6 & 1.55 \\
GEj & 862 & 1184 & 1.240 & 1.108 & 0.873 & 0.820 & -0.63 & -0.46 & 2.22 & 2.17 \\
\hline
\end{tabular}

\section{Estimation Results}

The results of the cross-sectional analysis of the basic model for the years 2002 and 2005 are reported in Table (4) (note 3).

The first group of frictions refers to the degree of development of the economy, both in the country of origin and the country of destination. The coefficients on these variables are significant with the expected signs and in accordance with the results generated in the financial and economic literature on portfolios holdings. Variable (GDPC) is statistically significant with a positive sign. This result concerns the country of origin as well as destination countries. However, the effect is more important for the country of origin (this is true for the years 2002 and 2005). This result is quite natural, as soon as the major economies generally have a level of technological and financial development fairly high, facilitating domestic investor's access to information on foreign markets, and consequently investment abroad. The positive effect of the country of destination indicates that investors are more inclined to hold shares of the economically developed markets, where the environment is relatively favorable and their detentions are carrying more additional wealth. Moreover, information on major economies and stock markets is more universally deployed or spread regarding the information in small markets. In addition, the variable of misery country, indicator of macroeconomic distress, is statistically significant and its negative sign is indicative of the risk aversion of investors around the globe. In fact, they prefer to hold shares in the safe markets, in which they have confidence (developed markets) and where the environment is stable. International investors want to avoid subsequent risk of macroeconomic distress involving significant losses for the entire economy (this result is also valid for the years 2002 and 2005).

For the variable of economic growth, proxied by real GDP growth adjusted for inflation, the result is unexpected. This one has a negative impact on cross-border detentions: during 2005, the variable (GGDP) was statistically significant at the $5 \%$ level with a negative sign. In fact, with regard to the distribution of equity portfolios flows across countries, we found that investors allocate most of their wealth invested abroad to developed countries. These exhibit lower values of economic growth than those experienced by emerging markets. This inclination of investments to developed countries explains the negative effect of economic growth on the cross-border portfolio holdings. This result also implies the superiority of the impact of information and economic development compared to economic growth. During 2002, the variable (GGDP) loses its significance but its sign remains negative.

The second group of indirect frictions on capital markets refers to the degree of financial market development in the source country as well as in the country of destination. The first proxy variable we considered is the sum of domestic credit provided by the banking sector and the country's domestic capitalization relative to GDP. The coefficients on the variable (Devfin) for countries of origin and destination are highly significant at the 1\% significance degree, with the expected positive signs. The effect is slightly larger for the country of origin, indicating that more and better financial institutions not only lead to more local financial activity but also to more investment in foreign markets. Also, the positive effect of financial market development in the country of destination shows that when the financial market in foreign countries is more developed, the terms of prices and investment opportunities are more favorable and investors will be more inclined therefore to hold portfolio in this economy (these results are valid for the years 2002 and 2005).

In addition, the proxy for market liquidity is the annual turnover rate measured as the annual volume of traded 
shares relative to the country's market capitalization (Turnover $\mathrm{r}_{\mathrm{j}}$. This variable is highly significant with a positive sign as expected for the two years of the study. In fact, the financial market liquidity refers to the ability to make quick transactions with a view to adjust portfolios and profits without prices suffering major effects. The result of the study is indicative of well-diversified investors around the world, who prefer to move towards more liquid markets because they are easier, faster and cheaper to transact. Investors also seek to avoid the liquidity risk corresponding to the loss from costs to liquidate a position.

In fact, during the 80s, for many investors, investing in foreign securities was almost impossible because their countries impose restrictions on the movement of capital. At this point, it is not unrealistic to assume that explicit barriers cause home bias in portfolios. Since the early 90s, almost all countries have liberalized their financial markets, at least to some extent. According to several theorists, nowadays, all developed markets and a number of emerging markets are open to foreign investors. In other words, the home and geographical bias in portfolios, highly persistent and still prevalent, cannot be explained by the controls of international capital flows. However, our results contradict those proclamations. The coefficients on both proxy variables of capital controls, (Capcon) and (Intercon), are positively significant for the country of destination as well as for the country of origin (this result is validated for the years 2002 and 2005). In other words, the more a country imposes restrictions on entry or exit of capital, the more investors underweight foreign securities in their portfolios. Similarly, all investors in the world will be more inclined to hold in their portfolios securities of countries imposing fewer restrictions on entry and exit of foreign capital.

Another group of implicit friction refers to the theory of corporate governance and the degree of investor protection. The estimation results show that the coefficients on the variables (liability $_{\mathrm{j}}$ ) (shareholder $\mathrm{j}_{\mathrm{j}}$ ) and (Disclosure ${ }_{\mathrm{j}}$ ) are significant with positive signs as expected (columns 3 and 8). It says that investors tend to hold securities in countries where investor protection is good. In fact, since insiders can extract substantial private benefits of control agents avoid investing in countries with weak institutions of investor protection. International investors are therefore more inclined to countries that provide the best protection of shareholders against insider abuses of corporate assets for personal purposes, in order to minimize the risk of expropriation. However, these variables lose their significance after the introduction of variables relating to capital controls.

In addition, the respective signs of the control variables are indicative of the low diversification of investors around the globe. The coefficient on the correlation variable of returns indices respective for countries of origin and destination $\left(\right.$ Correl $_{\mathrm{ij}}$ ) is positively significant. It says that investors are biased towards securities whose returns are highly correlated with the returns of domestic assets, that is to say, towards securities that offer few domestic risk diversifications. It is also essential to stress that the importance of the coefficient on this variable is indicative of the magnitude of the effect of correlation between financial markets in the distribution of capital flows across countries. This result is therefore a puzzle which remains to be explored. Moreover, as suggested by the standard theory of diversification, investors must hold the securities whose returns are weakly correlated with domestic asset returns, in order to benefit from the advantages of international diversification.

In addition, the assets return variable in the destination country $\left(\right.$ Return $\left._{\mathrm{j}}\right)$ is significant with a negative sign. In other words, investors will be more inclined to hold securities in markets that offer little return. Looking at the statistics on returns, we note that emerging markets exhibit relatively high returns relative to developed countries, which explains the negative sign associated with this variable. Moreover, investors have a preference for securities in financially and economically developed markets, without worrying too much about performance exhibited by these markets. Once again, the results highlight the dominance of informational or familiarity variables and variables related to financial and economic development, relative to market performance. 
Table 4. Effect of implicit and explicit frictions on assets allocation: Basic regression results

\begin{tabular}{|c|c|c|c|c|c|c|c|c|c|c|c|c|}
\hline & & Expected sign & & & 2005 & & & & & 2002 & & \\
\hline & $W_{i j, t}^{\mathrm{Reel}}$ & & (1) & (2) & (3) & (4) & (5) & (6) & (7) & (8) & (9) & (10) \\
\hline \multirow{8}{*}{ 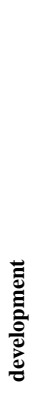 } & \multirow{2}{*}{$W_{i j, t}^{o p t}$} & \multirow{2}{*}{$(+)$} & 0.1402 & 0.1293 & 0.1260 & 0.1273 & 0.1285 & 0.1320 & 0.1242 & 0.1209 & 0.1245 & 0.1256 \\
\hline & & & $(4.63)^{\mathrm{a}}$ & $(4.00)^{\mathrm{a}}$ & $(4.00)^{\mathrm{a}}$ & $(4.08)^{\mathrm{a}}$ & $(4.15)^{\mathrm{a}}$ & $(5.40)^{\mathrm{a}}$ & $(4.80)^{\mathrm{a}}$ & $(4.70)^{\mathrm{a}}$ & $(4.92)^{\mathrm{a}}$ & $(4.97)^{a}$ \\
\hline & \multirow{2}{*}{$G D P C_{i}$} & \multirow{2}{*}{ ? } & 0.3505 & & & & & 0.3717 & & & & \\
\hline & & & $(6.39)^{\mathrm{a}}$ & & & & & $(4.80)^{\mathrm{a}}$ & & & & \\
\hline & \multirow{2}{*}{$G D P C_{j}$} & \multirow{2}{*}{$(+)$} & 0.0394 & & & & & 0.1523 & & & & \\
\hline & & & $(1.72)^{c}$ & & & & & $(6.45)^{a}$ & & & & \\
\hline & \multirow{2}{*}{ Detress $_{j}$} & \multirow{2}{*}{$(-)$} & -0.0101 & & & & & -0.0033 & & & & \\
\hline & & & $(-2.26)^{b}$ & & & & & $(-2.52)^{b}$ & & & & \\
\hline & \multirow{2}{*}{$G G D P_{j}$} & \multirow{2}{*}{$(+)$} & -0.0398 & & & & & -0.007 & & & & \\
\hline & & & $(-2.45)^{b}$ & & & & & $(-0.94)$ & & & & \\
\hline \multirow{4}{*}{ 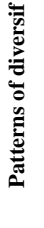 } & \multirow{3}{*}{ Correl $_{i j}$} & \multirow{3}{*}{$(-)$} & \multirow{4}{*}{$\begin{array}{l}0.3276 \\
(2.57)^{\mathrm{a}}\end{array}$} & 0.6346 & & & & & 0.499 & & & \\
\hline & & & & $(4.50)^{\mathrm{a}}$ & & & & & $(1.81)^{\mathrm{c}}$ & & & \\
\hline & & & & -0.1990 & & & & & -0.0058 & & & \\
\hline & Rendement $_{i j}$ & $(+)$ & & $(-2.01)^{b}$ & & & & & $(-1.75)^{c}$ & & & \\
\hline \multirow{6}{*}{$\stackrel{己}{\ddot{z}}$} & \multirow[t]{2}{*}{ Turnover $_{j}$} & \multirow{2}{*}{$(+)$} & & 0.1357 & 0.2885 & 0.2875 & 0.2902 & & 0.1738 & 0.3130 & 0.2493 & 0.2277 \\
\hline & & & & $(2.21)^{b}$ & $(4.79)^{a}$ & $(4.71)^{\mathrm{a}}$ & $(4.72)^{\mathrm{a}}$ & & $(2.34)^{b}$ & $(3.78)^{\mathrm{a}}$ & $(3.18)^{a}$ & $(2.99)^{a}$ \\
\hline & \multirow[t]{2}{*}{ Devfin ${ }_{i}$} & \multirow{2}{*}{$?$} & & 0.1911 & 0.2154 & 0.0832 & 0.0168 & & 0.2255 & 0.2710 & 0.0017 & 0.0015 \\
\hline & & & & $(4.38)^{\mathrm{a}}$ & $(4.78)^{\mathrm{a}}$ & $(1.89)^{c}$ & $(0.32)$ & & $(4.14)^{\mathrm{a}}$ & $(4.44)^{a}$ & $(3.24)^{\mathrm{a}}$ & $(2.69)^{a}$ \\
\hline & \multirow[t]{2}{*}{$\operatorname{Devfin}_{j}$} & \multirow{2}{*}{$(+)$} & & 0.1503 & 0.1594 & 0.1275 & 0.1071 & & 0.1116 & 0.1855 & 0.0013 & 0.001 \\
\hline & & & & $(2.72)^{\mathrm{a}}$ & $(2.71)^{\mathrm{a}}$ & $(2.62)^{a}$ & $(2.32)^{b}$ & & $(1.98)^{b}$ & $(2.86)^{\mathrm{a}}$ & $(2.26)^{b}$ & $(1.85)^{c}$ \\
\hline & Liabilito & $(+)$ & & & 0.0265 & 0.0236 & 0.0208 & & & 0.0056 & 0.0071 & 0.0134 \\
\hline & Lladilly $_{j}$ & (+) & & & $(1.69)^{c}$ & $(1.45)$ & $(1.26)$ & & & $(2.35)^{b}$ & $(0.41)$ & $(0.77)$ \\
\hline 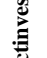 & Shareholder. & $(+)$ & & & 0.0376 & 0.0284 & 0.0262 & & & 0.0054 & 0.0036 & 0.0118 \\
\hline 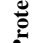 & & & & & $(1.80)^{c}$ & $(1.24)$ & (1.14) & & & $(1.73)^{c}$ & $(0.26)$ & $(0.80)$ \\
\hline & Dicl sus & $(+)$ & & & 0.0017 & 0.0007 & 0.001 & & & 0.0202 & 0.0311 & 0.0342 \\
\hline & Disclosure $_{j}$ & $(+)$ & & & $(1.67)^{c}$ & $(0.04)$ & $(0.05)$ & & & $(1.66)^{c}$ & $(1.72)^{c}$ & $(1.87)^{c}$ \\
\hline & $\mathrm{Capcon}_{i}$ & $(+)$ & & & & & & & & & & \\
\hline & & & & & & 0.0957 & & & & & 0.0642 & \\
\hline$\overline{\mathrm{O}}$ & $\mathrm{Capcon}_{j}$ & $(+)$ & & & & $(3.36)^{\mathrm{a}}$ & & & & & $(2.56)^{b}$ & \\
\hline जि & Intercon & $(+)$ & & & & 0.0250 & 0.2218 & & & & 0.0371 & 0.1277 \\
\hline & 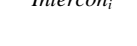 & (T) & & & & $(1.74)^{c}$ & $(3.69)^{\mathrm{a}}$ & & & & $(2.89)^{a}$ & $(2.92)^{\mathrm{a}}$ \\
\hline & & & & & & & 0.0558 & & & & & 0.0878 \\
\hline & Intercon $_{j}$ & $(+)$ & & & & & $(2.05)^{\mathrm{b}}$ & & & & & $(3.67)^{a}$ \\
\hline & Observation & & 1185 & 1185 & 1185 & 1185 & 1185 & 862 & 862 & 862 & 862 & 862 \\
\hline & $R^{2}$ & & 0.2720 & 0.2557 & 0.2830 & 0.2816 & 0.2525 & 0.3920 & 0.3853 & 0.3820 & 0.3885 & 0.3913 \\
\hline
\end{tabular}

\section{Robustness Tests}

To ensure the robustness of the results generated by the cross-sectional analysis, we conducted a panel analysis for 
the period that runs from 2002 to 2005. This analysis reports the individual and temporal heterogeneity and accordingly provides a good estimate. The dependent variables are the log of detentions of assets and the log of detentions of debt securities (total debt includes short-term debt and long-term debt). The results reported in Table (5) below confirm the results obtained from the analysis of cross-sectional model. (The variable "Protection ${ }_{j}$ " is the combined index of three indicators of investor protection already in use.)

Table 5. Robustness tests

\begin{tabular}{|c|c|c|c|}
\hline & Expected sign & $\log \left(1+a c t_{i j}\right)$ & $\log \left(1+o b l_{i j}\right)$ \\
\hline \multirow[t]{2}{*}{$\operatorname{Devfin}_{i}$} & (?) & 0.2108 & 0.1688 \\
\hline & & $(6.79)^{* * *}$ & $(2.95)^{* * *}$ \\
\hline \multirow[t]{2}{*}{$\operatorname{Devfin}_{j}$} & $(+)$ & 0.2144 & 0.0456 \\
\hline & & $(6.43)^{* * *}$ & (1.01) \\
\hline \multirow[t]{2}{*}{ Turnover } & $(+)$ & 0.1694 & 0.0026 \\
\hline & & $(1.70)^{*}$ & $(1.95)^{* *}$ \\
\hline \multirow[t]{2}{*}{ GDPC $_{i}$} & (?) & 0.0902 & 0.0821 \\
\hline & & $(32.28)^{* * *}$ & $(21.77)^{* * *}$ \\
\hline \multirow[t]{2}{*}{ GDPC $_{j}$} & $(+)$ & 0.0317 & 0.0434 \\
\hline & & $(10.47)^{* * *}$ & $(11.07)^{* * *}$ \\
\hline \multirow[t]{2}{*}{ Detress $_{j}$} & $(-)$ & -0.0047 & -0.0008 \\
\hline & & $(-1.72)^{*}$ & $(-0.24)$ \\
\hline \multirow[t]{2}{*}{ GGDP } & $(+)$ & -0.0196 & -0.0077 \\
\hline & & $(-2.46)^{* *}$ & $(-0.75)$ \\
\hline \multirow[t]{2}{*}{ Capcon $_{i}$} & $(+)$ & 0.0520 & 0.0502 \\
\hline & & $(5.37)^{* * *}$ & $(4.05)^{* * *}$ \\
\hline \multirow[t]{2}{*}{ Capcon $_{j}$} & $(+)$ & 0.0366 & 0.1004 \\
\hline & & $(3.55)^{* * *}$ & $(7.47)^{* * *}$ \\
\hline \multirow[t]{2}{*}{ Protection $_{j}$} & $(+)$ & 0.0433 & 0.0654 \\
\hline & & $(1.83)^{*}$ & $(1.55)$ \\
\hline \multirow[t]{2}{*}{ Correl $_{i j}$} & $(-)$ & 0.3017 & 0.3562 \\
\hline & & $(5.71)^{* * *}$ & $(4.93)^{* * *}$ \\
\hline \multirow[t]{2}{*}{ Return $_{j}$} & $(+)$ & -0.0035 & -0.0066 \\
\hline & & $(-4.63)^{* * *}$ & $(-6.83)^{* * *}$ \\
\hline Adjusted $\mathbf{R}^{2}$ & & 0.5757 & 0.4954 \\
\hline Observations & & 4208 & 3428 \\
\hline Specification & & MCG & MCG \\
\hline
\end{tabular}

$\mathrm{i}^{*(* *)(* *)}$ : values are significant at the $10 \%(5 \%)(1 \%)$ level.

Generally, investors collect information about foreign companies by analyzing their financial statements and historical data of stock markets. Accounting information is based on accounting rules and disclosure requirements which may differ significantly from those of their country of origin. The credibility of this information is determined to a large extent by the regulatory environment that varies from one country to another. Cross-border 
differences in accounting practices, disclosure requirements and regulatory environments cause information asymmetries between local and foreign investors. Foreign investors must translate and interpret this information in light of the appropriate legal and business environment, which leads to additional costs. Costs associated with investment in some countries may be significantly higher than in others. Accordingly, we will examine the impact of country accounting standards, disclosure requirements, regulatory environments and standards of corporate governance on the distribution of capital flows across countries. These legal and governance indices are expected to have a significant impact on the international allocation of portfolios. A brief description of these legal indices and of government is provided below:

\section{*Measure of Political Risk}

At this level, we add two variables to explain the political risk of the country of destination: The opacity index (OPAC) developed by PricewaterhouseCoopers is an average of five risk measures: an indicator of corruption, a measure of the legal and judicial opacity (including shareholder rights), an indicator of economic opacity, an indicator of the opacity of accounting practices or corporate governance and a factor that relates to the impact of regulatory opacity and uncertainty (note 4). High values of the opacity index indicate a lack of practice clear, precise and widely accepted in financial markets. Thus, we expect that the opacity index is negatively correlated with the detention of portfolios. This index recorded lower scores for developed countries (Finland (13), Great Britain (19) USA (29)) against higher scores for emerging countries (Argentina and Mexico (44) and India (48)). A second indicator of political risk is the International Index of perception of corruption (corruption). This index ranks countries in terms of the degree to which corruption is perceived to exist among public officials and politicians. It reflects the views of business people and analysts from around the world and ranges from 10 (highly clean) to 0 (highly corrupt), taking into account police corruption, business corruption, political corruption.... This index is developed by Transparency International and varies from 2 for Argentina and Indonesia to 8.7 for Switzerland.

\section{*Governance Indicators of Kaufmann et al. (2005)}

Kaufmann and al. (2005) present an update of the research project of global governance indicators. These indicators measure six dimensions of governance, namely: voice and accountability, political stability, government effectiveness, regulatory quality, rule of law and corruption. The data cover 212 countries and territories. The indicators are based on several variables measuring perceptions of governance, drawn from 35 separate data sources constructed by 32 various organizations worldwide. The authors assigned these individual measures to categories capturing these dimensions of governance and have used an unobserved components model to construct six aggregate indicators. These indicators are extracted from the website of the World Bank

The index of voice and accountability (VACC) is based on the concepts that measure the extent to which the State engages in repression of its citizens and uses force to restrict and control the society and the extent to which the State relies on tactics commonly considered illegitimate in the international community in carrying out internal security tasks. This index focuses on several indicators related to the political process, civil rights and institutions that facilitate citizen oversight of government actions.

The index of political stability and lack of violence (PS) combines indicators that measure the risk of destabilization of the power of government in a violent or unconstitutional way. Concepts measured include the risk of a military coup, the major insurrection, civil war, political assassination, the social malaise, the frequency of political killings or massacres, terrorism, etc.

Indices of government effectiveness (GE) and quality control (RQ) include indicators that focus on the government's ability to formulate and implement policies. The index of government effectiveness includes indicators that measure the quality of the bureaucracy, the competence of the State officials, the quality of public service and the credibility of the government's commitment to policies. The index of quality control consists of indicators related to regulations of exports, imports, commercial properties, stocks properties, banking, foreign investment, price controls, the tariffs, unfair competitive practice, etc.

Indices of the rule of law (RL) and control of corruption (CC) consider compliance, from citizens and government, for institutions that solve their conflicts and govern their interactions. The index of the rule of law includes variables measuring perceptions of the effectiveness and predictability of the judiciary, and the enforceability of contracts. It measures the concepts related to the applicability of private contracts and of government, the fairness of the judicial process, the judicial process promptly, violent and organized crime, trust in the legal system, the protection of patent and copyright, etc.

Finally, the index of control of corruption has different corruption indicators. It focuses on the extent of corruption 
in the political system, the level of severity of corruption in the state, the intrusion of the country's bureaucracy and corruption among officials.

The results showing the effect of these variables on the cross-border holding equity portfolios are presented in Table (7) below. It is important to note that the effect of these indices on the shareholding is considered separately, as the test VIF results show that their introduction into the global model induces a large disparity in the variance of the coefficients of the independent variables (the results of the test VIF are presented in the table (6)). Analysis is performed for the year 2005 and we redo the same work with a sample of countries of origin made by developed countries.

Table 6. Case of integrating governance variables in a single model: test VIF

\begin{tabular}{ccccc}
\hline & VIF & SQRT VIF & TOLERANCE & R-SQUARED \\
\hline Opac & 9.41 & 3.07 & 0.1062 & 0.8938 \\
Corrup & 65.44 & 8.09 & 0.0153 & 0.9847 \\
CC & 132.64 & 11.52 & 0.0075 & 0.9925 \\
RQ & 16.25 & 4.03 & 0.0615 & 0.9385 \\
VACC & 5.05 & 2.25 & 0.1980 & 0.8020 \\
RL & 26.80 & 5.18 & 0.0373 & 0.9627 \\
PS & 3.71 & 1.93 & 0.2696 & 0.7304 \\
GE & 33.80 & 5.81 & 0.0296 & 0.9704 \\
Average VIF & 36.64 & & & \\
\hline
\end{tabular}

Table 7. Effect of governance variables on assets allocation

\begin{tabular}{|c|c|c|c|c|c|c|c|c|c|}
\hline \multirow[b]{2}{*}{$W_{i, t, t}^{\text {Reel }}$} & \multirow{2}{*}{$\begin{array}{l}\text { Expected } \\
\text { Sign }\end{array}$} & \multicolumn{8}{|c|}{ 2005(1) } \\
\hline & & (1) & (2) & (3) & (4) & (5) & (6) & (7) & (8) \\
\hline \multirow{2}{*}{$W_{i j, t}^{o p t}$} & $(+)$ & 0.1355 & 0.1372 & 0.1381 & 0.1428 & 0.1377 & 0.1375 & 0.1373 & 0.1374 \\
\hline & & $(4.39)^{\mathrm{a}}$ & (4.47)a & (4.50)a & (4.68)a & (4.49)a & (4.48)a & (4.47)a & (4.47)a \\
\hline \multirow[t]{2}{*}{ Opac } & $(-)$ & -0.0085 & & & & & & & \\
\hline & & $(-2.22)^{b}$ & & & & & & & \\
\hline \multirow[t]{2}{*}{ Corrup } & $(+)$ & & 0.0386 & & & & & & \\
\hline & & & $(2.87)^{\mathrm{a}}$ & & & & & & \\
\hline \multirow[t]{2}{*}{$\mathrm{VACC}_{j}$} & $(+)$ & & & 0.0734 & & & & & \\
\hline & & & & $(1.81)^{\mathrm{c}}$ & & & & & \\
\hline \multirow[t]{2}{*}{$\mathbf{P S}_{\mathrm{j}}$} & $(+)$ & & & & 0.1084 & & & & \\
\hline & & & & & $(5.67)^{\mathrm{a}}$ & & & & \\
\hline \multirow[t]{2}{*}{$\mathbf{G E}_{\mathbf{j}}$} & $(+)$ & & & & & 0.0851 & & & \\
\hline & & & & & & $(2.51)^{b}$ & & & \\
\hline \multirow[t]{2}{*}{$\mathbf{R} \mathbf{Q}_{\mathbf{j}}$} & $(+)$ & & & & & & 0.0985 & & \\
\hline & & & & & & & $(2.49)^{\mathrm{b}}$ & & \\
\hline $\mathbf{R L}_{\mathbf{j}}$ & $(+)$ & & & & & & & 0.0917 & \\
\hline
\end{tabular}




\begin{tabular}{|c|c|c|c|c|c|c|c|c|c|}
\hline \multirow[b]{2}{*}{$\mathrm{CC}_{\mathrm{j}}$} & \multirow[b]{2}{*}{$(+)$} & & & & & & \multicolumn{3}{|c|}{$(2.79)^{\mathrm{a}}$} \\
\hline & & & & & & & & & 0.0838 \\
\hline \multirow[t]{2}{*}{ Correl $_{\mathrm{ij}}$} & $(+)$ & 0.8193 & 0.7893 & 0.7868 & 0.7855 & 0.7991 & 0.7897 & 0.7924 & 0.7829 \\
\hline & & $(5.43)^{\mathrm{a}}$ & $(5.50)^{\mathrm{a}}$ & $(5.13)^{\mathrm{a}}$ & $(5.48)^{\mathrm{C}}$ & $(5.44)^{\mathrm{a}}$ & $(5.32)^{\mathrm{a}}$ & $(5.44)^{\mathrm{a}}$ & $(5.38)^{\mathrm{a}}$ \\
\hline \multirow[t]{2}{*}{ return $_{j}$} & $(+)$ & -0.0030 & -0.002 & -0.0027 & -0.0029 & -0.0025 & -0.0024 & -0.0025 & -0.0027 \\
\hline & & $(-3.00)^{\mathrm{a}}$ & $(-3.1)^{\mathrm{a}}$ & $(-2.92)^{\mathrm{a}}$ & $(-2.88)^{\mathrm{c}}$ & $(-2.87)^{\mathrm{a}}$ & $(-2.81)^{\mathrm{a}}$ & $(-2.87)^{a}$ & $(-2.97)^{\mathrm{a}}$ \\
\hline Obs & & 1185 & 1185 & 1185 & 1185 & 1185 & 1185 & 1185 & 1185 \\
\hline $\mathbf{R}^{2}$ & & 0.2447 & 0.2461 & 0.2450 & 0.2349 & 0.2453 & 0.2453 & 0.2456 & 0.2458 \\
\hline
\end{tabular}

\begin{tabular}{|c|c|c|c|c|c|c|c|c|c|}
\hline \multirow[b]{2}{*}{$W_{i j, t}^{\text {Reel }}$} & \multirow{2}{*}{$\begin{array}{l}\text { Expected } \\
\text { Sign }\end{array}$} & \multicolumn{8}{|c|}{ 2005(2) } \\
\hline & & (1) & (2) & (3) & (4) & (5) & (6) & (7) & (8) \\
\hline \multirow{2}{*}{$W_{i j, t}^{o p t}$} & $(+)$ & 0.1753 & 0.1772 & 0.1780 & 0.1811 & 0.1777 & 0.1774 & 0.1771 & 0.1773 \\
\hline & & (4.68)a & (4.76)a & (4.79)a & (4.90)a & (4.77)a & (4.77)a & (4.75)a & (4.76)a \\
\hline \multirow[t]{2}{*}{ Opac } & $(-)$ & -0.0126 & & & & & & & \\
\hline & & $(-3.80)^{\mathrm{a}}$ & & & & & & & \\
\hline \multirow[t]{2}{*}{ Corrup } & $(+)$ & & 0.0644 & & & & & & \\
\hline & & & $(5.63)^{\mathrm{a}}$ & & & & & & \\
\hline \multirow{2}{*}{ VACC $_{j}$} & $(+)$ & & & 0.1933 & & & & & \\
\hline & & & & $(5.30)^{\mathrm{a}}$ & & & & & \\
\hline \multirow[t]{2}{*}{$\mathbf{P S}_{\mathrm{j}}$} & $(+)$ & & & & 0.1201 & & & & \\
\hline & & & & & $(4.08)^{\mathrm{a}}$ & & & & \\
\hline \multirow[t]{2}{*}{$\mathbf{G E}_{\mathrm{j}}$} & $(+)$ & & & & & 0.1658 & & & \\
\hline & & & & & & $(5.28)^{\mathrm{a}}$ & & & \\
\hline \multirow[t]{2}{*}{$\mathbf{R} \mathbf{Q}_{\mathbf{j}}$} & $(+)$ & & & & & & 0.1883 & & \\
\hline & & & & & & & $(5.34)^{\mathrm{a}}$ & & \\
\hline \multirow[t]{2}{*}{$\mathbf{R L}_{\mathbf{j}}$} & $(+)$ & & & & & & & 0.1694 & \\
\hline & & & & & & & & $(5.64)^{\mathrm{a}}$ & \\
\hline \multirow[t]{2}{*}{$\mathrm{CC}_{\mathrm{j}}$} & $(+)$ & & & & & & & & 0.1530 \\
\hline & & & & & & & & & $(5.58)^{\mathrm{a}}$ \\
\hline \multirow[t]{2}{*}{ Correl $_{i j}$} & $(+)$ & 0.5362 & 0.4900 & 0.38612 & 0.5255 & 0.4889 & 0.4677 & 0.4791 & 0.4580 \\
\hline & & $(2.88)^{\mathrm{a}}$ & $(3.01)^{\mathrm{a}}$ & $(2.28)^{\mathrm{b}}$ & $(2.78)^{\mathrm{a}}$ & $(2.87)^{\mathrm{a}}$ & $(2.62)^{\mathrm{a}}$ & $(2.91)^{\mathrm{a}}$ & $(2.77)^{\mathrm{a}}$ \\
\hline \multirow[t]{2}{*}{ return $_{j}$} & $(+)$ & -0.0028 & -0.0027 & -0.0026 & -0.0027 & -0.0021 & -0.0019 & -0.0021 & -0.0025 \\
\hline & & $(-2.72)^{\mathrm{a}}$ & $(-2.66)^{\mathrm{a}}$ & $(-2.64)^{\mathrm{a}}$ & $(-2.76)^{\mathrm{a}}$ & $(-2.16)^{b}$ & $(-2.00)^{\mathrm{b}}$ & $(-2.12)^{b}$ & $(-2.48)^{b}$ \\
\hline Obs & & 563 & 594 & 594 & 594 & 594 & 594 & 594 & 594 \\
\hline $\mathbf{R}^{2}$ & & 0.4819 & 0.4855 & 0.4844 & 0.4813 & 0.4838 & 0.4835 & 0.4849 & 0.4854 \\
\hline
\end{tabular}

$\mathrm{i}_{\mathrm{c}(\mathrm{b})(\mathrm{a})}$ : Values are significant at the $10 \%(5 \%)(1 \%)$ level.

The above table presents the regression results highlighting the impact of political risk indicators and governance indicators on the portfolios diversification bias internationally (in the second estimation, the sample of countries of origin is made only by developed countries). Indices of government opacity (OPAC) and corruption (corruption) 
are highly significant in explaining the distribution of cross-border detentions with the expected signs. The negative sign associated with the opacity indicator emphasizes the preference of investors to hold shares in countries with practices clear, precise and widely accepted in financial markets. The positive coefficient of the index of perception of corruption similarly shows that the increase of corruption in a country leads to an underweighting of securities of the latter in the portfolios of international investors. Also, the governance indicators of Kaufmann et al. (2005) are all positive and significant, implying that better governance in the country of destination would lead to more portfolios investment in the country.

This will result in low levels of geographical bias in portfolios of the country of origin against the country of destination. On an individual basis, the results for the total sample show that political stability (PS) has the greatest impact on portfolio holdings. An increase of $100 \%$ of political stability environment in the country of destination leads to an increase in cross-border holding by about $10 \%$. The change in the sample involves no change in the results. The coefficients of the variables are all significant with the same sign, except that the order of the effect of governance variables changes. The index of voice and accountability (VACC) has the largest impact on the holdings of investors in developed countries followed by the quality regulation environment. We also note that the homogenization of the sample of countries of origin increases the overall significance of the model. The R2 increases from 0.24 approximately in estimating the overall sample to 0.48 .

\section{Conclusions}

The aim of this research was to identify the factors behind the geographical bias in the allocation of portfolios, or the reasons why investors from different countries would allocate their resources differently. The diagnosis of portfolios structure highlights the limited diversification of investors around the world that exhibit a strong preference for domestic equities and devote to foreign securities a portion of their wealth less than that predicted by the standard theory of diversification. Similarly, international investments seem to be biased towards countries that offer to investors little domestic risk diversification, that is to say towards neighboring economies with idiosyncratic shocks highly correlated with domestic shocks. Our empirical estimates based on a comparison between the version of ICAPM in the absence of frictions in financial markets and the version in the presence of friction reveal several interesting results:

1) The geography of asset trade is partly explained by factors related to corporate governance and the level of investor protection. These prefer to allocate their wealth in countries that provide greater protection against the expropriation of corporate insiders.

2) Another result that contradicts several previous assertions is the effect that still existing of capital controls, which appear to prohibit the activity of investors internationally.

3) Investors are more willing to hold securities that offer few diversification opportunities for domestic risk, that is to say, the securities whose returns are highly correlated with returns on domestic assets. This stylized fact is a puzzle that remains to be explored.

4) The economic and financial development is an important determinant of the distribution of capital flows across countries.

\section{References}

Ahearne, A. G., Griever, W. L., \& Warnock, F. E. (2004). Information costs and home bias: an analysis of US holdings of foreign equities. Journal of International Economics, 62, 313-336. http://dx.doi.org/10.2139/ssrn.260228

Amadi, A., \& Bergin, R. (2008). Understanding international portfolio diversification and turnover rates. Journal of International Financial Markets, Institution and Money, 18(2), 191-206. http://dx.doi.org/10.1016/j.intfin.2006.09.003

Barber, B., \& Odean, T. (2001). Boys will be boys: gender, overconfidence, and common stock investment. Quarterly Journal of Economics, 141, 261-292. http://dx.doi.org/10.1162/003355301556400

Barber, B., \& Odean, T. (2002). Online Investors: Do the Slow Die First. Review of Financial Studies, 152, 455-487. http://dx.doi.org/10.1093/rfs/15.2.455

Barberis, N., \& Huang, M. (2009). Preferences with Frames: A New Utility Specification that Allows for the Framing of Risks. Journal of Economic Dynamics and Control, 33(8), 1555-1576. http://dx.doi.org/10.1016/j.jedc.2009.01.009

Barron, J. M., \& Ni, J. (2008). Endogenous Asymmetric Information and International Equity Home Bias: The Effects of Portfolio Size and Information Costs. Journal of International Money and Finance, 27, 617-635. 
http://dx.doi.org/10.1016/j.jimonfin.2008.02.003

Bhamra, H. S. (2004). International Stock Market Integration: A Dynamic General Equilibrium Approach. Working paper, London Business School.

Black, F. (1974). International Capital Market Equilibrium with Investment Barriers. Journal of Financial Economics, 1, 337-352.

Coeurdacier, N. (2009). Do trade costs in goods market lead to home bias in equities? Journal of International Economics, 77(1), 86-100. http://dx.doi.org/10.1016/j.jinteco.2008.10.005

Cooper, I., \& Kaplanis, K. (1994). What Explains the Home Bias Equity in Portfolio Investment. The Review of Financial Studies, 7, 45-60.

Coval, J. D., \& Markowitz, T. J. (2001). The geography of investment: informed trading and asset pricing. Journal of Political Economy, 109(4), 811-841.

Coval, J. D., \& Moskowitz, T. J. (1999). Home bias at home: local equity preference in domestic portfolios. Journal of Finance, 54, 2045-2073. http://dx.doi.org/10.1111/0022-1082.00181

Dahlquist, M., Pinkowitz, L., Stulz, R., \& Williamson, R. (2003). Corporate Governance and the Home Bias. Journal of Financial and Quantitative Analysis, 38(1), 87-110. http://dx.doi.org/10.2307/4126765

Gehrig, T. (1993). An information based explanation of the domestic bias in international equity investment. Scandinavian Journal of Economics, 95, 97-109.

Gordon, R. H., \& Hines, J. (2002). International taxation. NBER Working Paper N. 8854.

Heathcote, J., \& Perri, F. (2004). Financial Globalization and Real Regionalization. Journal of Economic Theory, 119(1), 207-243. http://dx.doi.org/10.1016/j.jet.2003.06.003

Huberman, G. (2001). Familiarity Breeds Investment. Review of Financial Studies, 14, 659-680. http://dx.doi.org/10.1093/rfs/14.3.659

Karlsson, A., \& Norden, L. (2007). Home sweet home: Home bias and international diversification among individual investors. Journal of Banking \& Finance, 31(2), 317-333.

Kho, B., Stulz, M., \& Warnock, F. E. (2009). Financial globalization, governance, and the evolution of the home bias. Journal of Accounting Research, 47(2), 597-635. http://dx.doi.org/10.1111/j.1475-679X.2009.00323.x

Kilka, M., \& Weber, M. (1997). Home bias in international returns expectations. Working Paper.

Lintner, J. (1965). The Valuation of Risky Assets and the Selection of Risky Investments in Stock Portfolios and Capital Budgets. Review of Economics and Statistics, 47(1), 13-37.

Magi, A. (2009). Portfolio choice, behavioral preferences and equity home bias. Quarterly Review of Economics and Finance, 49, 501-520.

Merton, R. C. (1987). A simple model of capital market equilibrium with incomplete information. The Journal of Finance, 42, 483-510.

Mondria, J., \& Wu, T. (2010). The puzzling evolution of the home bias, information processing and financial openness. Journal of Economic Dynamics and Control, 34, 875-896. http://dx.doi.org/10.1016/j.jedc.2009.12.004

Pinkowitz, L., Stulz, R. M., \& Williamson, R. (2002). Corporate governance and the home bias. NBER Working Paper N. 8680.

Portes, R., \& Rey, H. (2005). The determinants of cross-border equity flows. Journal of International Economics, 65, 269-296. http//dx.doi.org/10.1016/j.jinteco.2004.05.002

Sharpe, W. (1964). Capital Asset Prices: A Theory of Market Equilibrium Under Conditions of Risk. The Journal of Finance, 19(3), 425-442. http://dx.doi.org/10.2307/2977928

Solnik, B. (2008). Equity Home Bias and Regret: An equilibrium Model. Paris: Working Paper HEC.

Statman, M. (1999). Foreign Stocks in Behavioural Portfolios. Financial Analysts Journal, 55, 12-16.

Strong, N., \& Xu, X. (2003). Understanding the Equity Home Bias: Evidence from Survey Data. The Review of Economics and Statistics, 85, 307-312. http://dx.doi.org/10.1162/003465303765299837

Stulz, R. (1981). On the Effect of Barriers to International Investment. Journal of Finance, 36(4), 923-934.

Stulz, R. (2005). The limits of financial globalization. Journal of Finance, 60, 1595-1638. http://dx.doi.org/10.1111/j.1540-6261.2005.00775.x 


\section{Notes}

Note 1. The first class of models back to Sharpe (1964) and Lintner (1965). The second class of models is proposed by Black (1974), Stulz (1981), Merton (1987) and Cooper and Kaplanis (1994). Empirical tests of this class of models has been undertaken in an indirect way, see eg Copper and Kaplanis (1994). Stulz (1995) provides a comprehensive review of empirical tests of the ICAPM models with frictions on the capital markets. Versus indirect approaches, we address the impact of financial market frictions on portfolio choice directly.

Note 2. The data is downloaded from the website: www.freetheworld. com.

Note 3. The analysis was performed on two separate years in order to detect changes in patterns of diversification following years. The study sample is composed of the following countries: Argentine, Brazil, Chili, Colombia, Indonesia, Malaysia, Philippine, Singapore, Thailand, India, United States, United Kingdom, Turkey, Israel, Switzerland, Sweden, Spain, Portugal, Poland, Norway, New island, Netherlands, Mexico, Korea, Japan, Hong Kong, Italy, Ireland, Hungary, Greece, Germany, France, Finland, Denmark, Czech Republic , China, Canada, Belgium, Austria, Australia, Egypt, South Africa.

Note 4. Www.opacityindex.com. and www.kurtzmangroup.com 